\title{
The Effect of Problem-Based Learning Strategies and Cognitive Styles on Junior High School Students' Problem-Solving Abilities
}

\section{Miftahus Surur}

Postgraduate School,Universitas Negeri Malang, Indonesia, surur.miftah99@ gmail.com

\section{Nyoman Sudana Degeng}

Prof., Universitas Negeri Malang, Indonesia, nyoman.sudana.d.fip@um.ac.id

Punaji Setyosari

Prof., Universitas Negeri Malang, Indonesia, punaji.setyosari.fip@um.ac.id

\section{Dedi Kuswandi}

Assoc. Prof., Universitas Negeri Malang, Indonesia, dedi.kuswandi.fip@um.ac.id

This study aims to examine the effect of Problem Based Learning learning strategies, cognitive styles, and their interaction on students' problem-solving ability in social studies subjects. The type of this research is a quasi-experiment with nonequivalent control group design. The number of samples used was 120 students consisting of 60 students in the experimental class ( 2 classes) with the implementation of Problem Based Learning strategies and 60 students in the control class (2 classes) with the Direct Instruction strategy treatment. The research data was collected by the Group Embedded Figures Test (GEFT) instrument and problem-solving tests. The data analysis technique used is the Multivariate Analysis of Variance (MANOVA). This research resulted in several findings. Among them is a significant difference in students' solving abilities based on the application of learning strategies. Second, there is a significant difference in students' Problem-Solving abilities based on cognitive styles. Additionally, there was no correlation between learning strategies and cognitive styles on students' problem-solving abilities.

Keywords: problem based learning, cognitive style, problem-solving ability, learning, learning strategies

\section{INTRODUCTION}

Students' ability in understanding concepts is one of the education reform focuses and a key component of 21 st-century education (Geller, Son, \& Stigler, 2017) that can be used as a basis for obtaining problem-solving ability (Wismath, Orr, \& Mackay, 2015).

Citation: Surur, M., Degeng, I. N. S., Setyosari, P., \& Kuswandi, D. (2020). The Effect of ProblemBased Learning Strategies and Cognitive Styles on Junior High School Students' Problem-Solving Abilities. International Journal of Instruction, 13(4), 35-48. https://doi.org/10.29333/iji.2020.1343a 
According to the observations, the students in the learning process only memorized the material in the form of concepts. The teachers only provide the information by reconveying the definition of the concept; students are only limited to memorizing and knowing without understanding the purpose of the concept itself. Although students are also expected to utilize the concept in the problem-solving process. Thus, the students' ability is knowledge-oriented and limited to only face the test and achievement of test scores.

Learning is not only memorizing concepts or adding vocabulary, but students are expected to be able to understand concepts and their critical attributes (Arends, 2008). The teacher must also consider whether students use concepts in problem-solving and connect with real-life (Gultepe, Celik, \& Kilic, 2013). Besides, teachers are also expected to be skilled in identifying tasks and activities that will challenge student knowledge, and facilitate students to arrive at understanding concepts as a basis for problem-solving (Lopez, 2017).

Understanding concepts is an integration of cognitive processes (Loyens, Jones, Mikkers, \& van Gog, 2015) consisting of correlation, comparison, assimilation and reorganization of new knowledge with existing knowledge and transferring it to solve new problems (Saricayir, Ay, Comek, Cansiz, \& Uce, 2016). So it can be understood that the ability to understand concepts is closely related to the ability of students in problem-solving. There are five kinds of knowledge required for successful problem solving: understanding the facts, concepts, procedures, strategies, and beliefs (Fauziyah, Lant, Budayasa, \& Juniati, 2019). As (Rodzalan \& Saat, 2015) states that student involvement in the learning process can be through memorization, understanding and reflection. All of those processes require them to think to achieve effective learning outcomes and improve problem-solving ability.

Based on the explanation above, there needs to be an improvement in aspects of learning strategies, especially student-centered learning strategies in building and gaining knowledge. As (Dumford, Cogswell, \& Miller, 2016) states that learning strategies are specific patterns or combinations of various academic activities that students use to gain knowledge and have become an essential component in the success of learning.

In the case learning strategies, there are various studies explaining the learning strategies features that fit the students' characteristics, such as (Kresma, 2014) that found problem-based learning factors to train student sensitivity, student creativity (Geller et al., 2017), student independence (Barak \& Williams , 2007) and Problem-Solving (Yusof, Hassan, Jamaludin, \& Harun, 2012). This learning strategy is often referred to as Problem Based Learning (PBL), which is an effective learning strategy (Yusof et al., 2012) and can be utilized to obtain the skills needed in social studies classes (Zeliha, 2017).

Problem-based learning in educational practice remains hugely impactful on all levels of education (Erdogan, 2015) because integrating knowledge across disciplines makes students proactive in expanding their knowledge base and using various sources of information from textbooks and informal discussions with peers (Kadir, Abdullah, 
Anthony, Salleh, \& Kamarulzaman, 2016). PBL involves students' knowledge and skills identifications to apply those skills in new situations or achieve definite goals (Sangestani \& Khatiban, 2013).

PBL has been widely implemented in learning, and it had a positive effect (Sugiharto, Corebima, Susilo, \& Ibrohim, 2019). PBL is an appropriate strategy to promote critical thinking skills and Problem-Solving abilities because students are actively involved in handling significant problems (Yew \& Goh, 2016). PBL uses a constructivist approach, where students try to solve problems in everyday life in a collaborative environment (Mustofa, R.F \& Hidayah, 2020). In PBL, students are confronted with real-life problems that occur in the community, so students engage in innovative and creative learning processes in their problem-solving approaches. This is in line with what was conveyed by (Alrahlah, 2016) that the principal goal of the PBL approach is to show students the relevance of subject matter by delivering appropriate, realistic and practical context. In addition, PBL was built to promote various required learning outcomes and targets, including: (1) help students build a broad and flexible knowledge base, (2) help students to be effective collaborators, (3) enhance effective problem-solving ability, (4) motivate students to learn intrinsically, and (5) develop independent learning skills.

Problem scenarios used in PBL, called complex problems (that is, problems that can be solved in multiple ways) require several features that can encourage a high level of cognitive involvement (Loyens et al., 2015). Problems are presented in an unstructured and unresolved way so students will produce not only some thoughts about the cause of the problem, but various thoughts about how to overcome them (Strobel \& van Barneveld, 2009). Students in small groups usually work based on problems that are formulated to obtain information and choose the right self skills in investigating problems and offering the best solutions (Palupi, Subiyantoro, Rukayah, \& Triyanto, 2020)

Multiple types of research proved that PBL is successful and effective in improving students' understanding of concepts and problem-solving abilities. An empirical study recently added further evidence of the PBL effectiveness indicated by PBL groups which have a higher likelihood of conceptual change, outperforming independent-based, or lecture-based learning groups. This advantage occurs in two post-tests, namely after learning and one week later (Yew \& Goh, 2016). The (Loyens et al., 2015) finding shows the effect of PBL on conceptual change, showed that the PBL group outperformed both the lecture and the independent learning group at the posttest directly after learning. These results support the hypothesis that PBL can increase the likelihood of conceptual change. Besides, the research finding on the effect of PBL on students' achievement and problem-solving ability shows that students who learn through PBL are better at problem-solving ability compared to students who do not learn through PBL. This finding reinforces that the use of PBL is effective in improving students' problemsolving abilities (Kadir et al., 2016).

Apart from the learning strategy factors, the learning condition is critical to consider. As (Reigeluth, C.M., \& Cheliman, 2009) suggested that in organizing learning content, it is necessary to pay attention to variables of learning condition, one of which is the 
characteristics of students. Student characteristic is one of the conditions learning variables that are defined as aspects or qualities of individual students (Degeng, 2013). One of these characteristics is every student's uniqueness in obtaining and constructing knowledge that is called cognitive style. Cognitive style is the way individuals think, feel, and remember information (Sellah, Jacinta, \& Helen, 2017).

The cognitive style reflects individual characteristics in learning. Cognitive style is crucial because it determines the mechanism of individual processing information when solving problems, making decisions, or when interpreting stimuli and responses (AlSalameh, 2011). Cognitive style is a way that individuals use to process, store and use information to respond to tasks or situations in their environment (Margunayasa, Dantes, Marhaeni, \& Suastra, 2019). Coginitive style has the effect of a positive relationship on problem solving abilities as research findings (Jena, 2014) state that there is a significant influence and positive relationship between cognitive style and problem solving abilities. This is reinforced by the findings (Sudarman, Setyosari, Kuswandi, \& Dwiyogo, 2016) which states that there are differences in problem solving abilities in students with different cognitive styles. Cognitive styles can be distinguished by categorizing them in several ways, one of which is conducted by (Witkin, 1977), which identifies and groups a person based on the characteristics of the global-analytic continuum. Referring to (Witkin, 1977) grouping method, cognitive styles are divided into two groups, namely field-independent and field-dependent cognitive styles. An individual with a field-dependent cognitive style is someone who thinks globally, accepts existing structures or information, possesses a social orientation, prefers a profession requiring social skills, tends to follow existing goals and information, and tends to prioritize external motivation. Whereas an individual who possesses fieldindependent cognitive style is characterized with the ability to analyze objects separated from their environment, able to organize objects, possesses an impersonal orientation, prefers professions that do not require socialization and prioritize internal motivation.

The purposes of this study include: (1) to examine differences in Problem-Solving abilities between students who learn using the Problem Based Learning (PBL) strategy with those who do not, (2) to examine differences in Problem-Solving abilities between students who have field-independent cognitive style with students who have a fielddependent cognitive style, and (3) to study the interaction between the PBL and Direct Instruction strategy by considering different cognitive styles on students' ProblemSolving abilities.

\section{METHOD}

\section{Research Design}

This type of research is a quasi-experiment. Researchers cannot randomly choose subjects nor can modify the existing design. The researchers instead are forced to accept classes or groups of subjects that have been determined by the school (Setyosari, 2013). The factorial experimental design used was a $2 \times 2$ nonequivalent control group design. In this design, research subjects were not randomly chosen to be involved in the experimental and control groups (Setyosari, 2013). In this design, there are two groups 
which were selected purposively and were then given a pretest to find out the initial state of the tested groups. The experimental group applied the treatment of Problem Based Learning learning strategies while the control group applied the Direct Instruction learning strategies as the treatment.

The strategy used as the comparison in this study is the Direct Instruction strategy (direct learning). In general use, the term direct instruction refers to (1) instructional approach that is structured, ordered, and led by the teacher, and/or (2) presentation of academic content to students by the teacher, as in lectures or demonstrations. In other words, the teacher "directs" the instructional process or the teaching is "directed" at students. The direct instruction strategy creates a more organized learning atmosphere. The direct teaching model involves five stages or phases, namely: orientation phase, presentation/demonstration phase, structured training, guided training, and independent training.

\section{Research Subject}

The subjects of this study were 120 students consisting of 60 students in the experimental class ( 2 classes) with the treatment of the Problem Based Learning strategy and 60 students in the control class (2 classes) with the Direct Instruction strategy treatment. Researchers did not randomly select groups of research subjects, because they were organized from schools for administrative reasons, so researchers use intact groups.

\section{Data Collection Technique}

\section{Cognitive style test}

Cognitive style tests use a standardized measuring instrument called the Group Embedded Figures Test (GEFT) which is used to obtain psychometric data developed by (Witkin, H., Moor, C. A., Goodenough, D., \& Cox, 1977). The data consists of characteristics differences among individuals which reflects intellectual development that is divided into field-independent and field-dependent. GEFT tests the ability to find simple picture patterns hidden inside complicated picture patterns. The cognitive style identification of the subjects in this study was conducted by referring to the results of GEFT cognitive style test consisting of 25 items divided into 3 parts, where 7 items in part I are exercises while 18 items in parts II and III are the core of GEFT. Each subject is required to thicken the exact form of a simple picture hidden in a complex picture, then students are given a score of 1 if they answer it correctly. In this study, students who score $>9$ are classified as Field-independent (FI) and subjects who score $\leq 9$ are classified as Field-dependent (FD).

\section{Problem-solving test}

Problem-solving tests consist of test items in a descriptive form conducted before and after the treatment to measure students' Problem-Solving abilities. This test consists of 10 items referring to the content standards in the 2013 School curriculum of Indonesia for seventh-grade students in social science classes. Problem-solving ability tests are prepared by the researcher, under the direction and intensive guidance by the supervisor. 
The steps in preparing the test begin with determining the competency standard, determining the indicators, compiling the questions grid, compiling the questions, compiling the answer keys and scoring rules. Then the test is validated using a validation sheet with a Likert scale by experts who are appointed following the supervisor's recommendations.

To obtain data in accordance with the actual subject conditions, researchers need to ensure that the data collection instruments used are valid and reliable. The test instrument used to measure students' problem-solving abilities has been tested for validity through Product Moment Pearson Correlation and reliability testing with Alpha Cronbach Correlation. The validity test results show the Pearson Correlation value for all items exceeds 0.349 with a significance of less than 0.05 so that all instrument items are declared valid. While the reliability test results showed the Alpha Cronbach Correlation value of 0.786 with a significance of $0.00(<0.05)$ so that the instrument was declared reliable. With the fulfilment of valid and reliable criteria, the test instruments in this research can be used to measure students' problem-solving abilities.

\section{Data Analysis Technique}

The data analysis technique used in this research is the Multivariate Analysis of Variance (MANOVA). MANOVA is used because the number of dependent variables is more than one. Thus, the assumption underlying multivariate data analysis is that the dependent variable must be normally distributed and the data groups posses homogeneity.

\section{FINDINGS}

The data of this study was obtained through experimental learning activities as well as providing pretest and posttest to the research subjects to measure the level of students' Problem-Solving abilities. Before being tested using MANOVA, the research data must first meet the requirements for normality and homogeneity. The normality test used in this study is the Kolmogorov-Smirnov test with the significance of Lilliefors, while the homogeneity test is performed with Levene's Statistics. The results of the normality test are presented in Table 1 below.

Table 1

Normality Test Results of Research Data

\begin{tabular}{llllll}
\hline \multirow{2}{*}{ Variable } & \multicolumn{2}{l}{ Significance for Kolmogorov-Smirnov test } & \multirow{2}{*}{ Description } \\
\cline { 2 - 5 } & \multicolumn{2}{l}{ Experimental } & \multicolumn{3}{c}{ Control } \\
\cline { 2 - 5 } & Pretest & Posttest & Pretest & Posttest & \\
\hline Problem-Solving Abilities & 0.186 & 0.099 & 0.069 & 0.092 & Normal \\
\hline
\end{tabular}

Based on table 1 above, the normality test results of research data through the Kolmogorov-Smirnov test shows the lowest significance value of 0.069 and the highest significance value of 0.186 . Given that all data tested have a significance value greater than 0.05 , so the problem-solving ability data in the experimental and control classes are stated to be normally distributed and feasible be carried out by the MANOVA test.

The homogeneity test results using Levene's Statistics are shown in table 2 below. 
Table 2

Homogeneity Test Results of Research Data

\begin{tabular}{llll}
\hline Variable & \multicolumn{2}{l}{ Significance for Levene's Homogeneity Test } & Description \\
\cline { 2 - 3 } & Pretest & Posttest & \\
\hline Problem-Solving Abilities & 0,783 & 0,707 & Homogeneous \\
\hline
\end{tabular}

The test results in table 2 above show that the homogeneity test results of research data using the Levene's Statistics test obtained pretest significance value of 0.783 and posttest significance value of 0.707 . Given that all data have a significance value greater than 0.05 , the Problem-Solving ability data is claimed to be homogeneous and is feasible to be carried out by the MANOVA test.

Table 3

Normality Test Results of Cognitive Style

\begin{tabular}{llll}
\hline Variable & \multicolumn{2}{l}{ Significance for Kolmogorov-Smirnov test } & \multirow{2}{*}{ Description } \\
\cline { 2 - 3 } & Exsperiment & Control & \\
\hline Cognitive Style & 0,174 & 0,139 & Normal \\
\hline
\end{tabular}

The test results in table 3 above show that the normality test results of research data using the Kolmogorov-Smirnov test obtained exsperimental significance value of 0.174 and control significance value of 0.139 . Given that all data have a significance value greater than 0.05 , the cognitive style data in the experimental and control classes are stated to be normally distributed and feasible be carried out by the MANOVA test.

Table 4

Homogeneity Test Results of Cognitive Style

\begin{tabular}{llll}
\hline Variable & \multicolumn{2}{l}{ Significance for Levene's Homogeneity Test } & Description \\
\cline { 2 - 3 } & Experiment & Control & \\
\hline Problem-Solving Abilities & 0,081 & 0,223 & Homogeneous \\
\hline
\end{tabular}

The test results in table 4 above show that the homogeneity test results of research data using the Kolmogorov-Smirnov test obtained experimental significance value of 0,081 and control significance value of 0.223 . Given that all data have a significance value greater than 0.05 , the cognitive style data in the experimental and control classes are claimed to be homogeneous and is feasible to be carried out by the MANOVA test.

\section{The Effect of Learning Strategies on Students' Problem Solving Ability}

Table 3

Multivariate Test Results

\begin{tabular}{lllllll}
\hline Effect & & Value & F & Hypothesis df & Error df & Sig. \\
\hline Model & Pillai's Trace & .100 & $3.127^{\mathrm{b}}$ & 4.000 & 113.000 & .018 \\
& Wilks' Lambda & .900 & $3.127^{\mathrm{b}}$ & 4.000 & 113.000 & .018 \\
& Hotelling's Trace & .111 & $3.127^{\mathrm{b}}$ & 4.000 & 113.000 & .018 \\
& Roy's Largest Root & .111 & $3.127^{\mathrm{b}}$ & 4.000 & 113.000 & .018 \\
\hline
\end{tabular}

The multivariate test results in Table 3 show that the F class prices for Pillai's Trace, Wilks' Lambda, Hotelling's Trace, and Roy's Largest Root have a significance value of $0.018<0.05$. This shows that the F price for Pillai's Trace, Wilks' Lambda, Hotelling's 
Trace, and Roy's Largest Root are all significant. So it can be concluded that there is a significant influence between the variables of learning strategies on students' problemsolving abilities.

Furthermore, to determine difference in the students' problem-solving ability in the experimental class with the PBL strategy and the control class with the direct instruction strategy can be seen in the following table.

Table 4

Descriptive Statistics

\begin{tabular}{lllll}
\hline & Model & Cognitive Style & Mean & Std. Deviation \\
\hline Problem- & Problem Based & Field Independent & 7.14 & 2.065 \\
Solving & Learning & Field Dependent & 5.84 & 1.881 \\
Abilities & (Eksperiment & Total & 6.47 & 2.062 \\
\cline { 2 - 4 } & Class) & & 6.19 & 1.786 \\
& Direct Instruction & Field Independent & 4.46 & 2.219 \\
& (Control Class) & Field Dependent & 2.164 \\
\cline { 3 - 5 } & Total & Total & 5.38 & 1.967 \\
& Field Independent & 6.64 & 2.145 \\
& Field Dependent & 5.19 & 2.174 \\
\hline
\end{tabular}

Descriptively it can be seen in Table 4 that, students who learn with PBL strategies have an average value of 6.47 and students with Direct Instruction strategies have an average value of 5.38. Thus we can conclude that students who learn with PBL strategies have more excellent problem-solving abilities than students who learn with Direct Instruction strategies.

Table 5

Tests of Between-Subjects Effects

\begin{tabular}{lllllll}
\hline Source & Dependent Variable & $\begin{array}{l}\text { Type III Sum of } \\
\text { Squares }\end{array}$ & df & $\begin{array}{l}\text { Mean } \\
\text { Square }\end{array}$ & F & Sig. \\
\hline Model & $\begin{array}{l}\text { Problem-Solving } \\
\text { Pretest }\end{array}$ & 27.661 & 1 & 27.661 & 6.959 & .009 \\
\cline { 2 - 7 } $\begin{array}{l}\text { Problem-Solving } \\
\text { Posttest }\end{array}$ & 40.424 & 1 & 40.424 & 10.250 & .002 \\
\hline
\end{tabular}

The results of the $\mathrm{F}$ pretest on Problem-Solving ability obtained $\mathrm{F}_{\text {value }}$ of 6.959 and significance of 0.009 , while the value of $\mathrm{F}_{\text {statistic }}$ for $\mathrm{df} 1: 1$ and $\mathrm{df} 2: 118$ at $95 \%$ significance level was 3.920. Considering the value of Fcount > Ftable $(6.959>3.920)$ with the significance level of $0.009<0.05$, thus $\mathrm{H}_{1}$ is accepted and $\mathrm{H}_{0}$ is rejected, or it can be concluded that there is a significant difference in the results of the ProblemSolving pretest between students learning through PBL strategy and strategy Direct Instruction.

The results of the $\mathrm{F}$ posttest on Problem-Solving ability obtained $\mathrm{F}_{\text {value }}$ of 10.250 and significance of 0.002, while the value of $\mathrm{F}_{\text {statistic }}$ for $\mathrm{df} 1: 1$ and $\mathrm{df} 2: 118$ at $95 \%$ 
significance level was 3.920. Considering the value of Fcount $>$ Ftable $(10.250>3.920)$ with the significance level of $0.002<0.05$, thus $\mathrm{H}_{1}$ is accepted and $\mathrm{H}_{0}$ is rejected, or it can be concluded that there is a significant difference in the results of the ProblemSolving pretest between students learning through PBL strategy and strategy Direct Instruction.

\section{The Effect of Cognitive Style on Students' Problem Solving Abilities}

Table 6

Multivariate Test Results

\begin{tabular}{llccccc}
\hline Effect & & Value & F & Hypothesis df & Error df & Sig. \\
\hline Cognitive & Pillai's Trace & .344 & $14.792 \mathrm{~b}$ & 4.000 & 113.000 & .000 \\
Style & Wilks' Lambda & .656 & $14.792 \mathrm{~b}$ & 4.000 & 113.000 & .000 \\
& Hotelling's Trace & .524 & $14.792 \mathrm{~b}$ & 4.000 & 113.000 & .000 \\
& Roy's Largest Root & .524 & $14.792 \mathrm{~b}$ & 4.000 & 113.000 & .000 \\
\hline
\end{tabular}

The multivariate test results in table 6 show that the F class prices for Pillai's Trace, Wilks' Lambda, Hotelling's Trace, and Roy's Largest Root have a significance value of $0.000<0.05$. This shows that the F price for Pillai's Trace, Wilks' Lambda, Hotelling's Trace, and Roy's Largest Root are all significant. So it can be concluded that there is a significant influence between the variables of cognitive style on students' problemsolving abilities.

Furthermore, to determine the differences in students' problem-solving abilities who have field-independent cognitive styles and dependent cognitive styles can be seen in the following table.

Table 7

Descriptive Statistics

\begin{tabular}{lllll}
\hline & Model & Cognitive Style & Mean & Std. Deviation \\
\hline Problem- & Problem Based Learning & Field Independent & 7.14 & 2.065 \\
Solving & (Eksperiment Class) & Field Dependent & 5.84 & 1.881 \\
Abilities & & Total & 6.47 & 2.062 \\
\cline { 2 - 5 } & Direct Instruction & Field Independent & 6.19 & 1.786 \\
& (Control Class) & Field Dependent & 4.46 & 2.219 \\
& & Total & 5.38 & 2.164 \\
\cline { 2 - 5 } & Total & Field Independent & 6.64 & 1.967 \\
& & Field Dependent & 5.19 & 2.145 \\
& & Total & 5.93 & 2.174 \\
\hline
\end{tabular}

Descriptively it can be seen in Table 7 that, students who have field-independent cognitive styles have an average value of 6.64 and students who have field-dependent cognitive styles have an average value of 5.19. Thus we can conclude that students with field-independent cognitive styles have more excellent problem-solving abilities than students with field-dependent cognitive styles.

Tabel 8 
Tests of Between-Subjects Effects

\begin{tabular}{lllllll}
\hline \multirow{2}{*}{$\begin{array}{l}\text { Source } \\
\text { Cognitive }\end{array}$} & Dependent Variable & Sype III Sum of & & & \\
Style & Problem-Solving Pretest & 21.241 & 1 & 21.241 & 5.344 & .023 \\
\cline { 2 - 7 } & Problem-Solving Posttest & 68.323 & 1 & 68.323 & 17.324 & .000 \\
\hline
\end{tabular}

The results of the $\mathrm{F}$ pretest on Problem-Solving ability obtained $\mathrm{F}_{\text {value }}$ of 5.344 and significance of 0.023 , while the value of $F_{\text {statistic }}$ for df 1: 1 and $\mathrm{df} 2: 118$ at $95 \%$ significance level was 3.920. Considering the value of Fcount > Ftable (5.344 > 3.920) with the significance level of $0.023<0.05$, thus $\mathrm{H}_{1}$ is accepted and $\mathrm{H}_{0}$ is rejected, or it can be concluded that there is a significant difference in the results of the pretest of students' problem-solving skills in social studies subjects between those who have fieldindependent and field-dependent cognitive styles.

The results of the F posttest on Problem-Solving ability obtained $F_{\text {value }}$ of 17.324 and significance of 0.000 , while the value of $\mathrm{F}_{\text {statistic }}$ for $\mathrm{df} 1: 1$ and $\mathrm{df} 2: 118$ at $95 \%$ significance level was 3.920. Considering the value of Fcount $>$ Ftable $(17.324>3.920)$ with the significance level of $0.000<0.05$, thus $\mathrm{H}_{1}$ is accepted and $\mathrm{H}_{0}$ is rejected, or it can be concluded that there is a significant difference in the results of the pretest of students' problem-solving skills in social studies subjects between those who have fieldindependent and field-dependent cognitive styles.

Interaction between Learning Strategies, Cognitive Styles and Problem Solving Abilities

Table 9

Multivariate Test Results

\begin{tabular}{lllllll}
\hline Effect & & Value & F & Hypothesis df & Error df & Sig. \\
\hline Model $*$ & Pillai's Trace & .010 & $.290 \mathrm{~b}$ & 4.000 & 113.000 & .884 \\
Cognitive & Wilks' Lambda & .990 & $.290 \mathrm{~b}$ & 4.000 & 113.000 & .884 \\
Style & Hotelling's Trace & .010 & $.290 \mathrm{~b}$ & 4.000 & 113.000 & .884 \\
& Roy's Largest Root & .010 & $.290 \mathrm{~b}$ & 4.000 & 113.000 & .884 \\
\hline
\end{tabular}

The multivariate test results in table 9 show that the F class prices for Pillai's Trace, Wilks' Lambda, Hotelling's Trace, and Roy's Largest Root have a significance value of $0.884>0.05$. This shows that the F price for Pillai's Trace, Wilks' Lambda, Hotelling's Trace, and Roy's Largest Root are all insignificant. So it can be concluded that there is no interaction between learning strategies, cognitive styles and problem solving abilities.

\section{DISCUSSION}

In general, the results of the study indicate that the PBL strategy has a significant influence on students' problem-solving abilities. Students who learn with PBL strategies have the broadest opportunity to construct and use knowledge to find solutions in a collaborative environment (Mustofa, R.F \& Hidayah, 2020). (Arends, 2008) states that the essence of PBL presents a variety of problematic situations that are authentic and meaningful to students, which can serve as a stepping stone for investigation and inquiry. PBL is designed to help students develop thinking skills and problem-solving 
ability. The findings of this study support the hypothesis that PBL can increase the likelihood of conceptual change (Loyens et al., 2015). In addition, in research on the effect of PBL on students' problem-solving ability, the results showed that students in the experimental group were better at problem-solving ability compared to those not learning through PBL strategies. This finding reinforces the use of PBL as an effective strategy to improve students' problem-solving abilities (Kadir et al., 2016).

The cognitive style reflects individual images in learning. Cognitive style is a pattern of ongoing behaviour that determines how a person obtains and processes information (Sellah et al., 2017). Cognitive style is very important because it determines how to process information when solving problems or make decisions when interpreting stimuli and responses (Al-Salameh, 2011). In this study, it was found that students with a fieldindependent cognitive style have better problem-solving abilities compared to students who have a field-dependent cognitive style. This finding is in line with the results of research conducted by (Karaçam, Sedat; Digilli Baran, 2015) that there are significant differences in students' problem-solving abilities between those who have the Field Independent and Field Dependent cognitive styles.

The absence of interaction between the PBL learning strategy and the Direct Instruction strategy and the cognitive style of students' problem-solving abilities in social studies subjects indicates that in order to achieve maximum student problem-solving abilities, teachers only need to emphasize the learning process on one of the two variables studied, namely the application of student learning strategies or cognitive styles. Thus, it can be a choice for teachers to implement learning strategies or simply by paying attention to the cognitive styles that each student has.

\section{CONCLUSIONS}

The results of this study prove that (1) there is a significant difference in the ProblemSolving ability between students who learn using the Problem Based Learning and the Direct Instruction strategy, (2) there is a significant difference in the Problem-Solving abilities of students who posses field independent and field-dependent cognitive styles, and (3) there is no interaction between the learning strategies concerned (i.e PBL and Direct Instruction) and the cognitive style on students' Problem-Solving ability.

For further research, researchers should be able to choose different moderator variables, because from the research findings it is known that learning models and cognitive styles have a partially significant effect on students' problem solving abilities and there are no interactional relationships between variables.

\section{ACKNOWLEDGMENT}

We gratefully acknowledge the support from the promoter, co-promoter, chairman and all staffs of the Department of Instructional Technology, Postgraduate Program, State University of Malang, Indonesia on 2019 and LPDP from Ministry of Finance Republic of Indonesia. 


\section{REFERENCES}

Al-Salameh, E. M. (2011). A study of Al-Balqa' Applied University students cognitive style. International Education Studies, 4(3), 189-193. https://doi.org/10.5539/ies.v4n3p189.

Alrahlah, A. (2016). How effective the problem-based learning (PBL) in dental education. A critical review. The Saudi Dental Journal, 28(4), 155-161. https://doi.org/10.1016/j.sdentj.2016.08.003.

Arends, R. (2008). Learning To Teach (Belajar untuk Mengajar). Yogyakarta: Pustaka Pelajar.

Degeng, I. N. . (2013). Ilmu Pembelajaran. Bandung: Arasmedia.

Dumford, A. D., Cogswell, C. A., \& Miller, A. L. (2016). The who, what , and where of learning strategies. The Journal of Effective Teaching, 16(1), 72-88.

Erdogan, T. (2015). Research trends in dissertations on PBL: A content analysis study. Procedia - Social and Behavioral Sciences, 197, 308-315. https://doi.org/10.1016/j.sbspro.2015.07.142.

Fauziyah, N., Lant, C. Le, Budayasa, I. K., \& Juniati, D. (2019). Cognition processes of students with high functioning autism spectrum disorder in solving mathematical problems. International Journal of Instruction, 12(1), 457-478. https://doi.org/10.29333/iji.2019.12130a.

Geller, E. H., Son, J. Y., \& Stigler, J. W. (2017). Conceptual explanations and understanding fraction comparisons. Learning and Instruction, 52, 122-129. https://doi.org/10.1016/j.learninstruc.2017.05.006.

Gultepe, N., Celik, A. Y., \& Kilic, Z. (2013). Exploring effects of high school students' mathematical processing skills and conceptual understanding of chemical concepts on algorithmic problem solving. Australian Journal of Teacher Education, 38(10), 106122. https://doi.org/10.14221/ajte.2013v38n10.1.

Jena, P. C. (2014). Cognitive styles and problem solving ability of under graduate students. International Journal of Education and Psychological Research, 3(2), 71-76.

Kadir, Z. A., Abdullah, N. H., Anthony, E., Salleh, B. M., \& Kamarulzaman, R. (2016). Does problem-based learning improve problem solving skills?-A study among business undergraduates at Malaysian Premier Technical University. International Education Studies, 9(5), 166. https://doi.org/10.5539/ies.v9n5p166.

Karaçam, S., \& Digilli Baran, A. (2015). The effects of field dependent/field independent cognitive styles and motivational styles on students' conceptual understanding about direct current circuits. Asia-Pacific Forum on Science Learning and Teaching, 16(2), ar.6.

Kresma, E. N. (2014). Perbandingan Pembelajaran Konvensional dan Pembelajaran Berbasis Masalah terhadap Titik Jenuh Siswa Maupun Hasil Belajar Siswa dalam 
Pembelajaran Matematika. FKIP-Universitas Katolik Widya Mandala Madiun, 1, 152164.

Lopez, B. P. (2017). Theme: The 21st century adult learner. Educational Research and Reviews, 12(8), 540-548. https://doi.org/10.5897/ERR2016.2928.

Loyens, S. M. M., Jones, S. H., Mikkers, J., \& van Gog, T. (2015). Problem-based learning as a facilitator of conceptual change. Learning and Instruction, 38, 34-42. https://doi.org/10.1016/j.learninstruc.2015.03.002.

Margunayasa, I. G., Dantes, N., Marhaeni, A. A. I. N., \& Suastra, I. W. (2019). The effect of guided inquiry learning and cognitive style on science learning achievement. International Journal of Instruction, 12(1), 737-750. https://doi.org/10.29333/iji.2019.12147a.

Mustofa, R. F., \& Hidayah, Y. (2020). The effect of problem-based learning on lateral thinking skills. International Journal of Instruction, 13(1), 463-474.

Palupi, B. S., Subiyantoro, S., Rukayah, \& Triyanto. (2020). The effectiveness of Guided Inquiry Learning (GIL) and Problem-Based Learning (PBL) for explanatory writing skill. International Journal of Instruction, 13(1), 713-730. https://doi.org/10.29333/iji.2020.13146a.

Reigeluth, C.M., \& Cheliman, M. C. (2009). Instructional-design theories and model: Building a common knowledge base. Vol: III. New York: Taylor and Francis Publiser.

Rodzalan, S. A., \& Saat, M. M. (2015). The perception of critical thinking and problem solving skill among malaysian undergraduate students. Procedia - Social and $\begin{array}{lll}\text { Behavioral } \quad \text { Sciences, } & \text { 725-732. }\end{array}$ https://doi.org/10.1016/j.sbspro.2015.01.425.

Sangestani, G., \& Khatiban, M. (2013). Comparison of problem-based learning and lecture-based learning in midwifery. Nurse Education Today, 33(8), 791-795. https://doi.org/10.1016/j.nedt.2012.03.010.

Saricayir, H., Ay, S., Comek, A., Cansiz, G., \& Uce, M. (2016). Determining students' conceptual understanding level of thermodynamics. Journal of Education and Training Studies, 4(6), 69-79. https://doi.org/10.11114/jets.v4i6.1421.

Sellah, L., Jacinta, K., \& Helen, M. (2017). Analysis of student-teacher cognitive styles interaction: An approach to understanding learner performance. Journal of Education and Practice, 8(14), 10-20.

Setyosari, P. (2013). Metode Penelitian Pendidikan dan Pengembangan. Jakarta: Kencana Prenada Media group.

Strobel, J., \& van Barneveld, A. (2009). When is PBL more effective? A meta-synthesis of meta-analyses comparing PBL to conventional classrooms. Interdisciplinary Journal of Problem-Based Learning, 3(1). https://doi.org/10.7771/1541-5015.1046.

Sudarman, Setyosari, P., Kuswandi, D., \& Dwiyogo, W. D. (2016). The effect of 
learning strategy and cognitive style toward mathematical problem solving learning outcomes. IOSR Journal of Research \& Method in Education (IOSR-JRME), 6(3), 137143. https://doi.org/10.9790/7388-060304137143.

Sugiharto, B., Corebima, A. D., Susilo, H., \& Ibrohim. (2019). The pre-service biology teacher readiness in Blended Collaborative Problem Based Learning (BCPBL). International Journal of Instruction, 12(4), 113-130. https://doi.org/10.29333/iji.2019.1248a.

Wismath, S., Orr, D., \& Mackay, B. (2015). Threshold concepts in the development of problem-solving skills. Teaching \& Learning Inquiry, 3(1), 63-73. https://doi.org/10.2979/teachlearninqu.3.1.63?ref=no-xroute:594e5049afbe6a5a6bb9149d8cd0190b.

Witkin, H., Moor, C. A., Goodenough, D., \& Cox, P. W. (1977). Field-dependent and field-independent cognitive style and their educational implications. Review of Educational Research, 47, 1-64.

Yew, E. H. J., \& Goh, K. (2016). Problem-based learning: An overview of its process and impact on learning. Health Professions Education, 2(2), 75-79. https://doi.org/10.1016/j.hpe.2016.01.004.

Yusof, K. M., Hassan, S. A. H. S., Jamaludin, M. Z., \& Harun, N. F. (2012). Cooperative problem-based learning (CPBL): Framework for integrating cooperative learning and problem-based learning. Procedia - Social and Behavioral Sciences, 56(Ictlhe), 223-232. https://doi.org/10.1016/j.sbspro.2012.09.649.

Zeliha, N. B. (2017). The problem-based learning process: Reflections of pre-service elementary school teachers. Educational Research and Reviews, 12(4), 177-188. https://doi.org/10.5897/ERR2016.3045. 